UDC 631.95

\author{
ANASTASIIA BEKHTER, KRZYSZTOF ŚMIGIELSKI prof., dr hab. \\ Lodz University of Technology, Faculty of Biotechnology and Food, Institute of Food Chemistry Sciences \\ 116 Żeromskiego Street, 90-924 Lodz, Poland \\ E-mail: bekhteranastasiia@gmail.com https://orcid.org/0000-0001-6024-5278 \\ krzysztof.smigielski@p.lodz.pl https://orcid.org/0000-0002-4213-7852
}

\title{
NEGATIVE EFFECTS OF CHEMICALS USED AGAINST POTATO PATHOGENS ON THE NATURAL ENVIRONMENT
}

Purpose. This study focused on the analysis of chemicals most often used against potato pathogens and their negative impact on both water and soil ecosystems, as well as the search for alternative solutions. This aspect is extremely important since the quality and quantity of the crop depend mainly on the appearance of diseases on the plantations and postharvest storage conditions. Most often, the fight against pathogens is carried out with the help of fungicides. They, in turn, have a negative impact on water and soil systems, which affects the level of fertility and the quality of farmed products. Results. The analysis showed a negative effects of fungicides on the soil and water ecosystems. According to the reported results, the most dangerous are propamocarb hydrochloride, mancozeb, fluazinam and famoxate. Noteworthy, 30\% of the chemicals presented in this review are extremely toxic, $38 \%$ are moderately toxic, and $17 \%$ are toxic. It was found that the recurring usage of the same fungicides causes the adaptation of pathogens to the active substances while their replacement with other chemicals generates additional costs. The research indicates the necessity of modifying the current protection strategy by eliminating the most dangerous chemical compounds for nature and supplementing the protection program with environmentally safe biopreparations. A new strategy was proposed to fight potato pathogens based on the components obtained from domestic plants of the high biological activity potential (e.g. Curcuma longa, Allium sativum). An innovative approach to plant protection is the use of natural, effective and safe technologies to reduce or even eliminate the traditional chemical preparations. Conclusions. To prevent further degradation of the environment, the presented chemicals must be replaced by effective natural substances showing the antimicrobial activity. The prevention of further degradation of the environment caused by the development of agriculture is extremely important, because the quality and yield of crops depend on the soil quality, and the quality of crops affects human health.

Keywords: environmental problems, seed potatoes, potatoes, phytopathogens, fungicides

Bekhter Anastasiia, Śmigielski Krzysztof

Лодзський технологічний університет, факультет біотехнологій і харчових продуктів, Інститут хімї харчових продуктів

НЕГАТИВНІ ВПЛИВИ НА ПРИРОДНЕ СЕРЕДОВИЩЕ ХІМІЧНИХ ЗАСОБІВ, ЩО ВИКОРИСТОВУЮТЬСЯ ПРОТИ ПАТОГЕНІВ КАРТОПЛІ

Мета. Дослідження зосереджено на аналізі хімічних речовин, які найчастіше використовуються проти патогенів картоплі, та їх негативного впливу на водні та грунтові екосистеми, а також на пошук альтернативних рішень. Цей аспект $є$ надзвичайно важливим, оскільки якість та кількість врожаю залежать головним чином від появи захворювань на плантаціях та умов зберігання врожаю. Найчастіше боротьба з патогенами здійснюється за допомогою фунгіцидів. Вони, у свою чергу, негативно впливають на водні та грунтові системи, що впливає на рівень родючості та якість продукції, що вирощуються. Результати. Аналіз показав негативний вплив фунгіцидів на грунт і водні екосистеми. Згідно з отриманими результатами, найбільш небезпечними є пропамокарб гідрохлорид, манкозеб, флуазинам і фамоксат. Примітно, що 30\% хімічних речовин, представлених у цьому огляді, є надзвичайно токсичними, $38 \%$ - помірно токсичними, а 17\% - токсичними. Встановлено, що повторне використання однакових фунгіцидів призводить до адаптації патогенів до активних речовин, тоді як їх заміна іншими хімічними речовинами призводить до додаткових витрат. Дослідження вказує на необхідність зміни існуючої стратегії захисту шляхом усунення найбільш небезпечних хімічних сполук для природи та доповнення програми захисту екологічно безпечними біопрепаратами. Запропоновано нову стратегію для боротьби 3 патогенами картоплі на основі компонентів, отриманих з вітчизняних рослин з високим потенціалом біологічної активності (наприклад, Curcuma longa, Allium sativum). Інноваційний підхід до захисту рослин - це використання природних, ефективних і безпечних технологій для зменшення або навіть усунення традиційних хімічних препаратів. Висновки. Щоб запобігти подальшій деградації природного навколишнього середовища, представлені хімікати повинні бути замінені ефективними природними речовинами, що демонструють антимікробну активність. Запобігання подальшої деградації навколишнього середовища, спричиненої розвитком сільського господарства, є надзвичайно важливим, оскільки якість і врожайність сільськогосподарських культур залежать від якості грунту, а якість культур впливає на здоров'я людини.

Ключові слова: екологічні проблеми, насіння картоплі, картопля, фітопатогени, фунгіциди 


\section{Bekhter Anastasiia, Śmigielski Krzysztof НЕГАТИВНОЕ ВЛИЯНИЕ НА ПРИРОДНУЮ СРЕДУ ХИМИКАТОВ, ИСПОЛЬЗУЕМЫХ ПРОТИВ КАРТОФЕЛЕЙ}

Цель. Это исследование сосредоточено на анализе химических веществ, наиболее часто используемых против патогенных микроорганизмов картофеля и их негативного воздействия на водные и почвенные экосистемы, а также на поиск альтернативных решений. Этот аспект чрезвычайно важен, поскольку качество и количество урожая зависят главным образом от появления болезней на плантациях и условий хранения после сбора урожая. Чаще всего борьба с болезнетворными микроорганизмами осуществляется с помощью фунгицидов. Они, в свою очередь, оказывают негативное влияние на водные и почвенные системы, что влияет на уровень плодородия и качество выращиваемой продукции. Результаты. Анализ показал негативное влияние фунгицидов на почвенные и водные экосистемы. Согласно опубликованным результатам, наиболее опасными являются гидрохлорид пропамокарба, манкозеб, флуазинам и фамоксат. Следует отметить, что 30\% химических веществ, представленных в этом обзоре, являются чрезвычайно токсичными, 38\% - умеренно токсичными, а 17\% - токсичными. Было обнаружено, что повторное использование тех же самых фунгицидов вызывает адаптацию патогенов к активным веществам, в то время как их замена другими химическими веществами создает дополнительные расходы. Исследование указывает на необходимость изменения существующей стратегии защиты путем устранения наиболее опасных химических соединений для природы и дополнения программы защиты экологически безопасными биопрепаратами. Предложена новая стратегия борьбы с патогенами картофеля на основе компонентов, полученных из домашних растений с высоким потенциалом биологической активности (например, Curcuma longa, Allium sativum). Инновационный подход к защите растений заключается в использовании естественных, эффективных и безопасных технологий для сокращения или даже ликвидации традиционных химических препаратов. Выводы. Для предотвращения дальнейшей деградации окружающей среды представленные химические вещества должны быть заменены эффективными природными веществами, обладающими антимикробной активностью. Предотвращение дальнейшей деградации окружающей среды, вызванной развитием сельского хозяйства, является чрезвычайно важным, поскольку качество и урожайность сельскохозяйственных культур зависят от качества почвы, а качество сельскохозяйственных культур влияет на здоровье человека.

Ключевые слова: экологические проблемы, семенной картофель, картофель, фитопатогены, фунгициды

Potatoes are vegetables that are cultivated on all continents. Their harvest ranks fourth in the world's total crops. It is estimated that the total area of potatoes planting all over the world is around 19 million hectares, and the annual crops are around 325 million tons, with an average yield of $16.8 \mathrm{t} / \mathrm{ha}$. The quality and quantity of the crop depend mainly on the appearance of diseases on the plantations and postharvest storage conditions. Bacterial pathogens cause diseases of various etiologies: from dry rot of tubers to potato deterioration [1], [2]. The most dangerous of these pathogens are: Clavibacter michiganensis, Ralstonia solanacearum, Streptomyces, Fusarium and Rizoctonia solani, Helminthosporium solani, and Alternaria solani. About 40 phytopathogenic viruses, 54 species of phytopathogenic fungi, 19 species of nematodes, 3 species of phytoplasm and 11 species of bacteria that attack potato tubers have been identified to date. These pathogens cause serious problems in nearly all countries where potatoes are grown in large amounts. Potato bacilli are currently a serious problem for around thirty countries in the world. In 1904, the disease was detected in Germany. Over the last forty years it has spread to many other regions, such as America, Russia, and also a part of northern
Europe. Initially, it was thought that the disease develops only in a cold climate. However, at the beginning of the 21 st century, the epidemic broke out in the Netherlands, France, Greece and Spain.

The quality of plant derived products that are exported by all countries is regulated basing on the principles and practices of plant biosecurity, presented by the European and Mediterranean Plant Protection Organization (EPPO). In case of potatoes, this system is expected to limit the spread of pathogens that may be associated with either potatoes or potato products. An advantage of the system is that it enables to eliminate from the market the products derived from the areas where a pathogen has been detected. The state control system allows to export good quality potatoes from all countries like from the countries that have not been attacked by the phytopathogens. The purpose of the control system is to detect the presence of a pest, as well as to prevent its spread. The extent of control is determined on the basis of the risk assessment. However, the methods enabling restoration of the aquatic and soil ecosystems after elimination of the pathogens have not been regulated by the EPPO principles. The lack of compulsory restoration leads to a decrease in 
the soil fertility and the degradation of the system as a whole.

Experimental procedures. The literature survey enabled to select the most dangerous pathogens and describe the negative impact of these microorganisms.

One of most deleterious is Clavibacter michiganensis (abbreviated as CMS) which is transferred by molluscs (Ralstonia solanacearum) and causes the ring rot, being one of quarantine-requiring diseases (listed in the EPPO A2 list) that are often encountered in Europe. These organisms multiply easily under conditions of moisture and refrigeration storage. The spread of these organisms is controlled by the use of international phytosanitary practices and the qualification of production [3].

Heavily infested tubers usually rot without germination while less damaged plants create fewer tubers. The loss of potato yield in particular years can reach $35-40 \%$. The most characteristic symptoms of the disease are gradual yellowing of the shoots and wilting of leaves. The disease is transmitted by insects, as well as through the agricultural equipment. [4].

The infested planting material most often leads to an epidemic. The problem is to identify this pathogen, which is considered asymptomatic. For this reason, the ring rot may be identified even after several years. It was found that there is a chance of infiltration of the pathogen even with undamaged peel - through the eyelets of tubers.

To identify potato bacteriology, the studies should include at least two diagnostic methods like the enzyme immunoassay (ELISA) and immunofluorescence (IF) methods. Also the polymerase chain reaction (PCR) method may be used [5], [6].

In the case of detecting the ring rot, the farmer suffers from large economic losses due to the utilization of infected potatoes and disinfection of the farm (premises, equipment), the ban on growing potatoes for 4 years in commodity production on the territory and for 7 years in the production of certified seed potatoes.

Potatoes are also attacked by actinomycetes Streptomyces scabies that are pathogens of tuber skin disease. The greatest problem for Poland in the case of seed potatoes and edible potatoes are silver scab and common scab. The agent causing the potato disease are Streptomyces bacteria. The most deleterious of them are Streptomyces scabies and Streptomyces turgidiscabie. The disease can be transmitted through an agricultural device or seed potatoes. It can be caused by the purchase of infected seed potatoes, excess nitrogen in the soil or an increase in the tempera- ture of the soil above $20^{\circ} \mathrm{C}$. A characteristic feature of this disease is scabious swelling [7].

The quality of the final product depends on the health condition of the tubers. Potato tubers are in turn sensitive to diverse weather conditions, soil conditions and agrotechnical strategies. After detecting the symptoms, they can be eliminated from commercial circulation. The average loss of potato yield can reach 5$52 \%$.

The pathogen Streptomyces scabies tends to settle in dry sandy soil at $\mathrm{pH} 3.5-5.5$ and achieves full activity in the range from $25^{\circ} \mathrm{C}$ to $28^{\circ} \mathrm{C}$. Potato rot has the following characteristics: brown injuries, sometimes with shades of red or violet, and rough surface of potato tubers. During the storage at lower temperatures, the actinomycetes goes into an anabolic state. Rot on potatoes does not pose a threat to human health, however, the product loses its nutritional value: in comparison to healthy tubers, the starch content is reduced twice [8].

Potatoes may be attacked also by a phytopathogenic Rhizoctonia solani. The disease develops during the growth and gradually affects the stalks and root of potatoes. Sprouts are susceptible to decay during intense rainfall and cold. The indicator of the disease is the appearance of brown spots. This form of the disease affects the growth intensity, number and strength of the shoots, which affects the market value of potatoes. During the development of the infection, the leaves turn yellow and curl up. Considering the serious damage caused by this fungal disease, chemical preparations are often used to fight it [9].

Another pathogen, Helminthosporium solani resides in soil where it infects tubers. It is multiplied actively at temperatures ranging from 2 to $30^{\circ} \mathrm{C}$. It actively reproduces during the storage, which facilitates the action of other pathogens. Symptoms of the disease are clearly visible in spring, especially after planting the tubers. Indicators of infection are gray-brown or gray-yellow spots which are first smooth and later they change to slightly pressed [10].

The pathogen occurring in all regions is Alternaria solani. It most intensively develops in the arid areas of the south. On the leaves, the disease manifests itself throughout the growing season. The first signs of infection can be detected already during potato budding. It is difficult to diagnose this type of pathogen because the symptoms are similar to the lack of trace elements in the soil, such as magnesium and potassium. The pathogen forms dry brown spots both outside and inside the potato. During hot 
weather, the stains can crumble creating deep holes [11].

Soil is thought to be the main source of infection with the fungi of the genus Fusarium (Palmer, Kommedahl 1969). After planting the plant in the infected soil, the destruction process starts from the roots, blocking the root system. Blockage of the root system leads to dysfunction of the vascular system, causing death. Plants are particularly sensitive during flowering, and high temperature contributes to the growth of the fungus.

The first signs of infection are the appearance of bleached leaves at the top of the plant, later they lose the turgor. The attacked plant completely disappears within a few days.

However, there are methods to prevent phytopathogic infections by using different chemicals.

To maximize the crops and to be competitive in the world market, aggressive control methods such as fungicides have been used for decades by farmers. These chemicals not only adversely affect the pathogens but also aquatic and soil ecosystems.

The most popular are fungicides which inhibit the growth of fungi, like e.g. copper compounds, mandipropamid, and cyazofamide.

The list of active substances recommended in 2018 in Poland by the Program for the Protection of Agricultural Plants is presented in Table [3].

One of these chemicals is chlorothalonil (Ref: DS 2787), which is a broad-spectrum fungicide. It was first used as an antifungal agent in 1964. This volatile substance is barely soluble in water, and therefore it has a low potential for groundwater contamination. However, its bioaccumulation poses a threat to environment. It is irritant and moderately toxic to birds and bees, but considered more toxic to aquatic organisms [14], [15].

Another broad-spectrum fungicide is Propineb (Ref: BAY 46131), which showes a tendency to accumulate in the environment. It was first launched on the market in 1965. According to ECHA (European Chemicals Agency) this preparation does not pose a threat to manufacturers, importers or downstream users of this substance [16].

Another broad-spectrum fungicide is Propamocarb hydrochloride, which is very toxic. It causes sensitization and allergies to the skin. It has a proven deleterious effect on the aquatic environment and may cause its degradation [17], [18].
The next fungicide, Cymoxanil (Ref: DPX T3217), which went on sale in 1970, stops the growth of fungi locally, and is able to penetrate the leaves during incubation. Because of the shortterm effect, up to two days, it is usually used in mixtures with other protective agents [19].

One of the most popular preparations used against phytopathogens in Poland is Mankozeb. It is extremely toxic and accumulates in aquatic organisms. It also negatively affects the development of the fetus in the uterus. According to the data presented at the conference "Mancozeb Event Poland" (November 22, 2016, Mała Wieś near Grójec), this substance was enrolled on the list of toxic compounds that may be banned in the EU countries [20].

Less toxic is Dimetomorf (Ref: CME 151), which is a cinnamic acid derivative. It has been used since 1993 in European countries. Because of the instability it is usually used with other preparations, to extend the spectrum of action [21].

Azoxystrobin, which was first used in 1998 , is characterized by the rapid penetration of the root system and spreading along the plant's stems and leaves. It is often used for disinfection of leaves and seeds. It has a negative impact on aquatic organisms and may cause allergies [22].

Metalaxyl-M (Ref: CGA 329351) is a universal fungicide that destroys pathogens populating the soil. It was first used in the USA in 1996. As a volatile compound, it may have a negative effect on the respiratory tract [23].

Fluazinam (Ref: IKF 1216), which is used to combat gray mold and other fungal pathogens, enables to control fungal pathogens associated with the soil. It is very toxic to aquatic organisms and may lead to degradation of the aquatic environment [24].

Difenoconazole is used in agriculture against a wide range of phytopathogens. Although its impact does not depend on weather conditions, at temperatures below $12{ }^{\circ} \mathrm{C}$ its effectiveness decreases. It penetrates both soil and water environments, and is bioaccumulated. It is considered moderately toxic to most aquatic organisms [25].

Famoxat is very toxic, and causes irreversible degradation of the aquatic and soil environment. The long-term contact has a negative impact on human health while the short-term contact may cause an allergic reaction [26]. 
List of fungicides used against most often encountered potato pathogens

Table

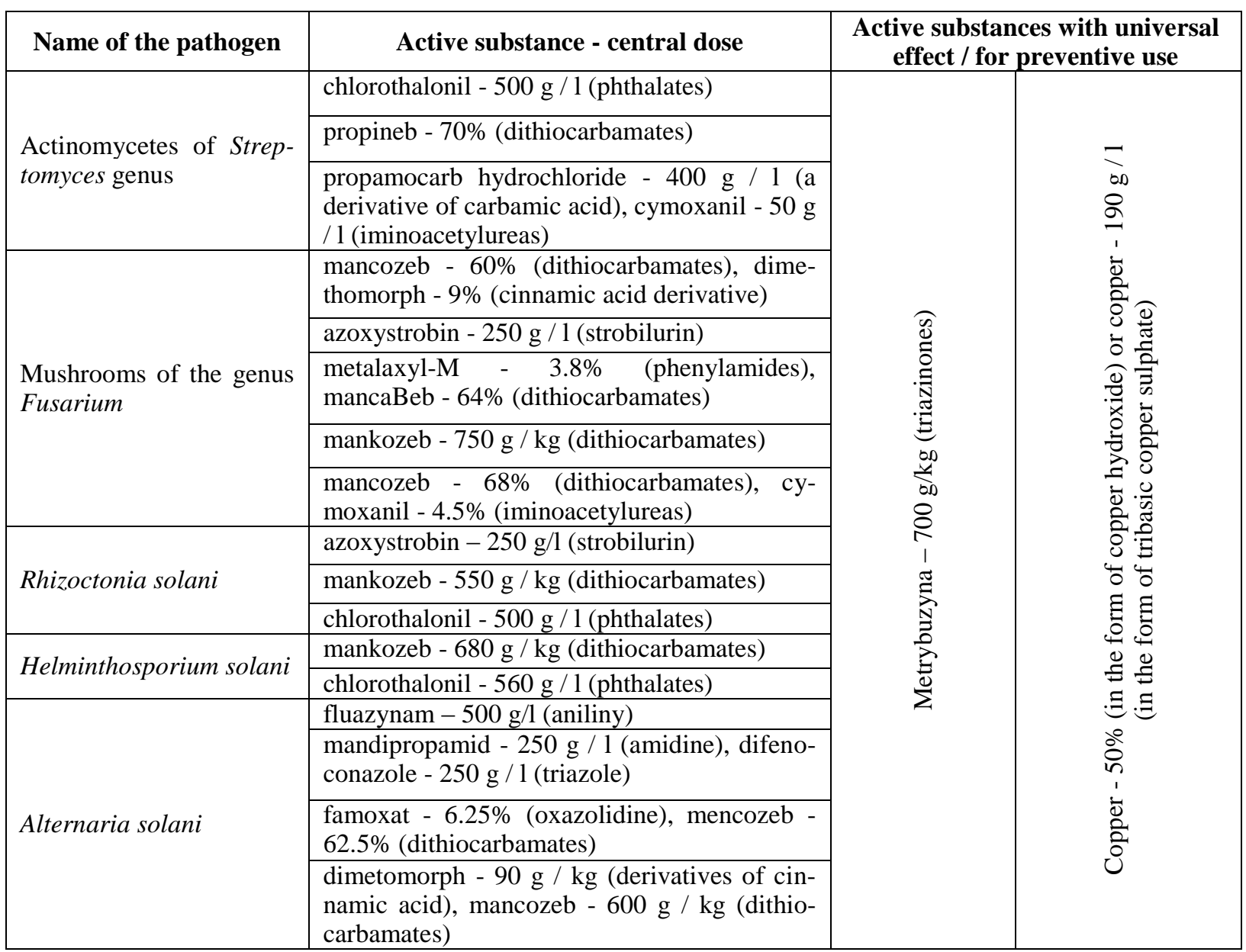

Methibusin, acting as an inhibitor of photosynthesis, is relatively non-toxic and nonirritating. Its long-term action is related to the rapid penetration into the soil and leaves. It is moderately toxic to fish. It is decomposed in soil within 1-3 months while it is rapidly degraded in water under the influence of light. At $20^{\circ} \mathrm{C}$ and $\mathrm{pH}$ of 12.5 , it is resistant to dilute acids and bases [27].

One of the safest methods of protecting plants against phytopathogens is based on application of copper compounds. These compounds have been successfully used against bacteria and fungi for over 150 years. One of the main drawbacks of the copper compounds is the possibility of destroying or damaging plants during application. To neutralize the acidic character of copper sulphate, it is often used in a mixture with lime. Because the action of copper compounds does not depend on weather conditions, they may be used all round the year [28].

Alternative solution The problem can be solved by searching for natural components with potential antimicrobial activity. Plant extracts can be an alternative to currently used fungicides to control phytopathogens, because they are a rich source of bioactive components.

Turmeric long (Curcuma longa) is one of the best known perennial plants with antimicrobial and anti-inflammatory properties. The plant comes from India, and belongs to the ginger family. Turmeric greens contain 1.7$5.5 \%$ starch, essential oil and curcumin dye (difluoromethyl). The chemical structure of the dye was determined by Roughley and Whiting (1973). Its melting point ranges from 165 to $175^{\circ} \mathrm{C}$. Curcumin is soluble in ketones, ethanol, alkali, chloroform and acetic acid. The nutritional value per $100 \mathrm{~g}$ is $354 \mathrm{kcal}$, the spice contains vitamins (C and B6) as well as micro- and macroelements (magnesium, iron, copper, zinc, sodium, manganese, potassium and phosphorus) [29].

Research carried out by the Korean Institute of Chemical Technology (MOO-KEY KIM, GYUNG-JA CHOI and HOI-SEON LEE) showed that Curcuma longa is fungicidal. For the experiment, extracts from the whole plant were prepared using four different sol- 
vents (hexane, ethyl acetate, butanol and chloroform). The structural determination of the active isolate was made by means of spectroscopic analysis. The tests of antimicrobial activity, which were conducted for six different products (one of which was potato) showed that the extracts were active against Botrytis cinerea, Erysiphe graminis, Phytophthora infestans, Puccinia recondita, Pyricularia oryzae and Rhizoctonia solani.

The fungicidal activity against Erysiphe graminis, Phytophthora infestans and Rhizoctonia solani was demonstrated using $1000 \mathrm{mg}$ / 1 of Curcuma longa hexane extract. The extract, which was extracted with ethyl acetate, showed a fungicidal activity against Botrytis cineria, Phytophthora infestans, Puccinia recondita and Rhizoctonia solani. The remaining extracts showed the weak antifungal activity [30].

The researchers (Hu Y., Zhang J., Kong W., Zhao G., Yang M.) who analyzed the antifungal properties of the essential oil obtained from Curcuma longa found that the antifungal activity was caused by the inhibition of the synthesis of ergosterol, mitochondrial ATPase, malate dehydrogenase and succinate dehydrogenase [31].

This study provided evidence that Curcuma longa is the potential antifungal agent that is completely environmentally friendly.

Garlic (Allium sativum) has long been used as an anti-infection agent with the strong antiviral and antifungal activities. The main component responsible for the treatment of viral diseases is allicin. It also contains: adenosine, pectin, flavonoids and minerals (magnesium, phosphorus, iron and selenium).

The antifungal activity of Allium sativum was studied by Ulla Bång (2008). The in vitro and in vivo study, demonstrated the potency of Allium sativum against three pathogens (Fusarium solani, Phoma foveata and Helminthosporium solani). Noteworthy, the antifungal effect did not cause any visible damage to potato tubers [32].

The plants with potential antimicrobial activity reported in the literature include: common onion (Allium cepa), peppermint (Mentha pieperita), caraway carnasse (Carum carvi), and venomous crab (Flos caryophylli).

\section{Conclusion}

The brief information presented in this mini-review, provides evidence of the negative effects of fungicides on the soil and water ecosystems. Because all the chemicals are deleterious for the ecosystems, all of them have the negative impact on the quality and yield of crops. The most dangerous are propamocarb hydrochloride, mancozeb, fluazinam and famoxate. According to the presented data, 30\% of the chemicals are extremely toxic, $38 \%$ are moderately toxic, and $17 \%$ are toxic. It was found that the recurring usage of the same fungicides causes the adaptation of pathogens to the active substances while their replacement with other chemicals generates additional costs. To prevent further degradation of the environment, the presented chemicals must be replaced by effective natural substances showing the antimicrobial activity. One of potential solutions of this problem are plant extracts, being a rich source of biologically active components. These extracts may be an environmentally friendly alternative to the currently used fungicides.

The prevention of further degradation of the environment caused by the development of agriculture is extremely important, because the quality and yield of crops depend on the soil quality, and the quality of crops affects human health.

\section{References}

1. The EU potato sector - statistics on production, prices and trade 2016: The_EU_potato_sector statistics_on_production,_prices_and_trade. Available at: https://ec.europa.eu/eurostat/statistics

2. Top Potato Producing Countries Europe 2018. Available at: https://www.potatopro.com/europe/potatostatistics

3. EPPO Global Database. Available at: https://gd.eppo.int

4. European and Mediterranean Plant Protection Organization/ Organisation Européenne et Méditerranéenne pour la Protection des Plantes. Available at: https://www.eppo.int/ACTIVITIES/plant quarantine/A2 list

5. Pastrik, K.H. (2000). Detection of clavibacter michiganensis subsp. Sepedonicus in potato tubers by multiplex pcr with coamplification of host dna, European Journal of Plant Pathology, 106(2). 155-165

6. López, M.M., Bertolini, E., Olmos, A., Caruso P., Gorris, M.T., Llop, P., Penyalver, R., Cambra, M. (2003). Innovative tools for detection of plant pathogenic viruses and bacteria, International Microbiology, 6(4), 233-243 
7. Lees, A. K., Cullen, D. W., Sullivan, L., Nicolso, M. J. (2002). Development of conventional and quantitative real-time PCR assays for the detection and identification of rhizoctonia solani AG-3 in potato and soi, Plant Pathology. 51, $293-30$

8. Lindholm, P.,Kortemaa, H., Kokkola, M., Haahtela, K., Salkinoja-Salonen, M., Valkonen, J.P. T. (2007). Streptomyces spp. Isolated from potato scab lesions under nordic conditions in Finland, Plant Disease, 22.

9. Babcock, M. J., Eckwall, E.C., Schottel, J. L.(1993). Production and regulation of potato-scab-inducing phytotoxins by Streptomyces Scabies, Journal of General Microbiology. 139, 1579-1586. Printed in Great Britain

10. Talbot Brewer M., Larkin R. P. (2005). Efficacy of several potential biocontrol organisms against Rhizoctonia solani on potato, Elsevier Crop Protection, 24(11). 939-950

11. Cullen, D. W. , Lees, A.K. , Toth, I. K. , Duncan, J. M. (2001). Conventional PCR and real-time quantitative pcr detection of Helminthosporium Solani in soil and on potato tubers, European Journal of Plant Pathology, (4), 387-398

12. Van der Waals, JE., Korsten, L., Slippers, B. Genetic diversity among Alternaria solani isolates from potatoes in South Africa. Plant Disease. 88 (9), 959-964

13. EPPO Global Database: Available at: https://gd.eppo.int

14. Bruynzeel, D.P. \& van Ketel, W.G. (1986) Contact dermatitis due to chlorothalonil in floriculture. Contact Derm., 14, 52-68.

15. Occupational Health Services Inc. (1987). Material Safety Data Sheet: Chlorothalonil. 2/25/87. NY.

16. Hazardous Chemical Information System (HCIS), Safe Work Australia propineb (ISO) Available at: http://hcis.safeworkaustralia.gov.au/HazardousChemical/Details?chemicalID=3693

17. UN Globally Harmonized System of Classification and Labelling of Chemicals (GHS)

GHS Classification Tree Available at: http://www.unece.org/trans/danger/publi/ghs/ghs welcome e.html

18. U.S. Environmental Protection Agency. Cymoxanil; Pesticide Tolerances for Emergency Exemptions. Federal Register Document 97-12475. May 13, 1997.

19. International Agency for Reasearch on Cancer.World Health Organization.IARC Monographs on the Identification of Carcinogenic Hazardz to Humans:m . Available at: https://monographs.iarc.fr

20. Gowan Comercio Internacional e Servicos, Lda, Rua Ivens No 3 B, Dona Mecia Building, 6th Floor, 9000046 Funchal, Madera, Republika Portugalska. Załącznik do zezwolenia MRiRW nr R- 206/2016 z dnia 17.10. $2016 \mathrm{r}$.

21. J.R. Bertelsen, E.de Neergaard and V.Smedegaard-PetersenFungicidal effects of azoxystrobin and epoxiconazole on phylloshere fungi,senescence and yield of winter wheat.Department of Plant Biology, Royal Votorinary and Agrocultural University, Thorvaldsensvej 40, DK-1871 Frederiksberg C, Denmark.

22. Buser, H-R., Müller, M.D., Poiger, T., Balmer, M. E. Environmental Behavior of the Chiral Acetamide Pesticide Metalaxyl: Enantioselective Degradation and Chiral Stability in Soil Swiss Federal Research Station, CH-8820 Wädenswil, Switzerland.

23. Smith, F. D., Phipps, P. M., Stipes, R. J. (1992) Fluazinam: A New Fungicide for Control of Sclerotinia Blight and Other Soilborne Pathogens of Peanut. Peanut Science, 19(2), 115-120. https://doi.org/10.3146/i0095-3679-19-2-14

24. Fengshou Dong, Jing Li, Bezhan Chankvetadze, Yongpu Cheng, Jun Xu, Xingang Liu, Yuanbo Li, Xiu Chen, Carlo Bertucci, Daniele Tedesco, Riccardo Zanasi, and Yongquan Zheng (2013). Chiral Triazole Fungicide Difenoconazole: Absolute Stereochemistry, Stereoselective Bioactivity, Aquatic Toxicity, and Environmental Behavior in Vegetables and Soil, Environ. Sci. Technol., 47 (7), 3386-3394.

25. Bogucka, B., Dubis, B., Wszelaczyńska, E., Pobereżny, J., Mozolewski, W. (2017). Effect of mineral fertilization on harmful components in potato tubers with purple-blue flesh, Scientiarum Polonarum ACTA, Agricultura $16(4), 191-198$.

26. Urbanowicz, J. (2014). Herbicydy do walki z chwastami na plantacjach ziemniaka, Ziemniak Polski. (2), 3541.

27. Dorn B. , Musa T., Krebs H., Men Fried P., Forrer Rudolf H. (2007). Control of late blight in organic potato production: evaluation of copper-free preparations under field, growth chamber and laboratory conditions, European Journal of Plant Pathology . 119(2), 217-240.

28. Ammon HPT, Wahl MA 1991. PHARMACOLOGY OF CURCUMA LONGA. Planta Med 57: 1-7.

29. Moo-Key Kim, Gyung-Ja Choi, And Hoi-Seon Lee, (2003). Fungicidal property of curcuma longa 1. Rhizome-derived curcumin against phytopathogenic fungi in a greenhouse. J. Agric. Food Chem. 51, 1578-1581

30. Hu, Y., Zhang, J., Kong, W., Zhao, G., Yang, M. (2017). Mechanisms of antifungal and anti-aflatoxigenic properties of essential oil derived from turmeric (Curcuma longa 1.) on Aspergillus flavus. Food Chemistry, Apr 1;220:1-8. DOI:10.1016/j.foodchem.2016.09.179

31. Ulla Bång (2007). Screening of natural plant volatiles to control the potato (Solanum Tuberosum) Pathogens Helminthosporium Solani, Fusarium Solani, Phoma Foveata And Rhizoctonia Solani. Potato Research, (2), 185-203

Надійшла до редколегії 14.04.2019 